\title{
CORRESPONDENCE
}

\section{Licking Darwin}

SIR - How absurd to hold that Darwinism cannot be falsified. All it would take is a single clear demonstration of the de novo creation of a complex organism, well adapted to its environment, and the Darwinists would be legless.

G.P. VINSON

Department of Biochemistry and Chemistry, The Medical College of St Bartholomew's Hospital, London ECI, UK

\section{Weed control}

SIR - As May emphasizes ${ }^{1}$, all possible steps should be taken to prevent the intrusion of noxious weeds into new regions. That article paid rather less adequate attention to weeds that are aiready established. Consider two hypothetical situations. Suppose it was discovered that one of these weeds contained a valuable fibre. Within a few years we would have a conservation programme to save the weed from extinction. Suppose enterprising adolescents found that one of the weeds contained a hallucinogen. The $\$ 15$ million quoted as the annual cost of water hyacinth control in Florida and Louisiana would be "chicken feed" compared with what drug control authorities would spend on elimination.

Water hyacinth has been studied for so long that components as dramatic as these are unlikely to be found in it. Nevertheless, it is a prodigious producer of biomass and is often conveniently located on broad areas of water from which mechanical collection is easy. Twenty one years ago $^{2}$ I made " . . . a plea for some reorientation of thinking in areas suffering from, or threatened with, water hyacinth. There is a case for directing some research towards finding uses for the pest instead of concentrating all efforts on its eradication."

Since then, the pest has made great headway. Less headway has been made on finding uses for it. Interest is, however, increasing. Chibbar and Singh ${ }^{3}$ fed cows on silage made from water hyacinth and paddy straw, and there have been several recent papers in the Indian Journal of Animal Science extending that work. Hyacinth is deliberately cultivated in China for pig feed. It is a component of the mixtures used for biogas fermentation in many countries. These and other uses are surveyed in Making Aquatic Weeds Useful (US National Academy of Sciences, 1976) and in Handbook of Utilization of Aquatic Plants (Food and Agricultural Organization, 1979). This is encouraging. But the amount of effort put into finding uses for water hyacinth and other weeds is a tiny fraction of the effort put into killing them. I do not suggest deliberate encouragement, only the assignment of comparable importance to both lines of approach.

Harpenden, Herts, UK

N.W. PIRIE

1. May, R.M. Nature 290, 85-86 (1981)

\section{Cafeteria feeding}

SIR - I wonder if I am alone in my dislike of the term "cafeteria feeding" used first, I think, by Rothwell and Stock in 1979 (Rothwell, H.J. \& Stock, M.J. Nature 281, 31; 1979). According to the Concise Oxford Dictionary a cafeteria is a "restaurant in which customers fetch food and drink from a counter" which is hardly an accurate description of the behaviour of rats allowed to make their own choice of palatable items of food. I would like to suggest that, before it is too late, editors of scientific journals ask authors to use a more accurate description, for example to replace "cafeteria diet" by "a selfselected palatable diet" (abbreviated SSPD) or other equivalent term.

University of Bristol, UK

A.S. COLE

\section{Cancer causation}

SIR - The recent series of articles ${ }^{1-3}$ on cancer causation prompts me to respond. Without defending Epstein and Swartz, I would like to offer several alternative explanations to some of the examples which Cairns used to argue his case that somatic mutations play little or no part in human carcinogenesis.

Although Cairns' novel hypothesis is to be welcomed as a stimulus to new experimental approaches, I feel that he has summarily dismissed a significant amount of evidence consistent with the somatic mutations theory of cancer. Furthermore, carcinogenesis is a multi-step process and there are probably several distinct molecular mechanisms that can "cause" and influence carcinogenesis, not the least of which are somatic mutations ${ }^{4}$.

Specifically, Cairns argues that the apparent lack of common fatal cancers in xeroderma pigmentosum (XP) individuals (the cells from whom lack proper DNA repair causing them to be hypermutable to many mutagens, including the ultraviolet component of sunlight) is evidence that the production of mutations in XP cells is probably irrelevant to carcinogenesis. There are at least two reasonable alternative explanations why XP ratients rarely get cancers other than skin tumours $^{5}$. The XP patients normally do not live iong enough to manifest these internal tumours (an explanation cited but dismissed by Cairns) and most cancers are the result of initiation (mutagenesis) and promotion (amplification of an initiated cell into a clone where additional genetic or epigenetic changes can occur). One can explain the production of skin tumours in XP on this hypothesis since, using this concept, repaired sunlight-induced lesions in the skin cells of XP patients will lead to both cell killing and mutated viable cells.

In effect, the large numbers of killed cells will "force" the surviving, but initiated, cells to repopulate the necrotic tissue, giving rise to clones of dysfunctional cells. During that repopulation phase, some of these initiated cells are further exposed to more mutagens. Thus, the cytotoxicity caused by the inability to repair large amounts of sunlight-induced DNA damage can be considered an "indirect promoter", much in the manner of a partial hepatectomys. On the other hand, internal cells of XP patients, which are exposed to chemical mutagens that mimic sunlightinduced DNA damage, probably are not exposed to high enough levels constantly to cause significant cell killing, as occurs in the skin. In effect, these initiated cells will not be promoted! Only after long periods of time or exposure to chronic effective levels of exogenous or endogenous tumour promoters will internal tumours appear.

A second argument used by Cairns to support this thesis of genetic transposition was the discussion on Bloom's syndrome. I agree with Cairns that Bloom's syndrome might be a "better" model for studying carcinogenesis, but for a different reason. At the time of writing his paper, Cairns was not aware of the observation that Bloom's syndrome seems to be a "mutator" syndrome 6 , in that it spontaneously generates mutations in their somatic tissue. In effect, Bloom's cells can generate mutations in any proliferation cell of the body, with or without exposure to "environmental" mutagens. This would explain the wide range of tumours (and other clinical features) associated with the syndrome, and would also fit the initiation/ promotion model, since each time a spontaneous mutant cell arises and then divides, it can enhance the probability of additional genetic imbalances.

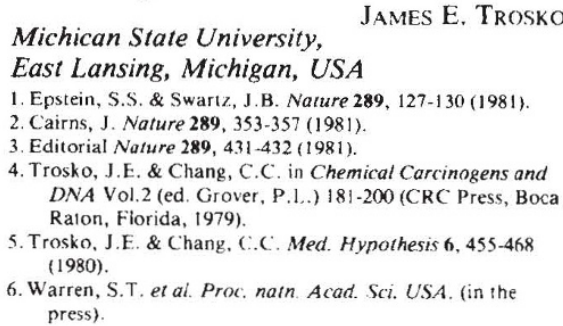

\section{Genes and free will}

SIR - Asked to dissociate themselves from the neo-Nazi use of their names and theories, John Maynard Smith' and Richard Dawkins 2 have both done so. Professor Maynard Smith's unequivocal couple of sentences will be no surprise to scientists who know him as a man of principle and integrity; his letter will give no comfort to the National Front or any similar grouping.

It is a pity, though, that Dr Dawkins appears to think that the issue I sought to raise in my letter is of a parallel with the relatively harmless debate on cladistics and dialectics which has kept us entertained over recent months. If it were not for that dreary little edge of "reds under the bed" of which Stephen Jay Gould reminds us ${ }^{3}$, I suspect we could look forward to Nature with the same enthusiasm as once we had for Beano. However, the issues are not the same. Racism directly haunts the streets of our cities. In our laboratories neither Dawkins nor I live in the daily hazard that the obscene rubbish of the New Nation and its followers fosters in the East End or New Cross. When Dawkins disdains the ephemera of mere "human politics", or accuses his critics of being as guilty as the Nazis of dragging the elegant purity of his neo-Darwinsim into the litter of the city streets, he does so at the peril of a repetition of the tragedies of the 1930 s.

Of course we must all beware of the fallacy Continued on page 432 


\section{CORRESPONDENCE}

Continued from page 356

of confusing the origins with the content of a scientific theory 4 . Any student of sociology or philosophy of science is likely to be intrigued by the social framework of the emergence of sociobiological theory over the last decade and its relationship to the New Right ideology5. But having explored that link, it is the task of critics of sociobiology to expose what they see as its methodological, internal inadequacies (for example, refs 6 and 7).

If sociobiologists want to avoid the charge that they believe that biology is destiny, they should beware of telling magazines that they know "why we do what we do" or entitling their books The Selfish Gene, The Inevitability of Patriarchy or On Human Nature. The trouble is that they want to have their cake and eat it. They imperialize the human sciences (vide the first paragraph of Sociobiology, The New Synthesis) and are embarrassed by the outcome. This is why the final chapters of Dawkins' or Wilson's books are so confusing. Having set out the inexorable destiny of genetic predispositions to xenophobia, aggression, patriarchy or whatever, they invoke the possibility of a human conscious prospect of overcoming these predispositions. As Dawkins puts it in his letter, with respect to philandering males "many humans (have) some at least momentary intention of overcoming their polygamous tendencies. Many even succeed in this', For Wilson euphenics may overcome any "hereditary tendency" to acquire xenophobia. Free will, intentions and wishes (or Dawkins' memes) like the US cavalry, come galloping over the horizon in the nick of time to rescue us from our genes.

But where does our free will, etcetera come from? How can we be both genetically programmed robotic DNA survival machines and have the extraordinary capacity to transcend these programs? The truth is that sociobiological determinism, when challenged, collapses into the weakest sort of Cartesian dualism. For consistent materialists - like Gould, whom Dawkins quotes, and, I hope, myself too - we must argue that wishes, intentions etc. are as much, or as little, "given" by our genes as any other aspect of our human existence. The interesting thing about humans is that the fact that we can change what we do is as much part of our biology as how we do what we do. To give the example used in my review of Wilson - if humans were quadruped and not biped, their social arrangements would be different; that humans are biped is genetically "given", therefore the human social order is genetically given. The point is that such genetic syllogisms are boringly uninteresting about either any of the crucial aspects of differences between human societies or the changes that occur within any given society. They neither explain nor predict apartheid in South Africa, cultural revolutions in China, Born Again Christianity in the United States, the welfare state or its dismantling under Mrs Thatcher in Britain, still less any of our individual proclivities.

On such questions then, biology has to be silent. It is because self-styled sociobiologists are not silent (I challenge anyone to read The Selfish Gene and come away without a clear impression of Dawkins' views of what biology has to say about the Welfare State, sexual mores or microeconomics) that their work both trivializes important social and biological questions and is so amenable to neo-Nazi and New Right ideology.

\section{The Open University}

Milton Keynes, UK

Steven Rose

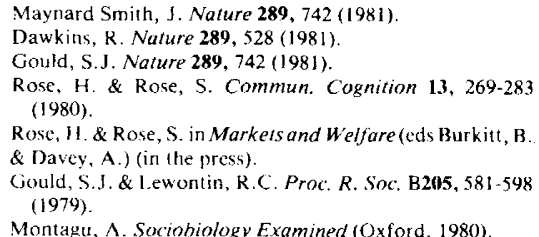

\section{Conservation sites}

SiR - The attack on conservation sites by Muir (Nature 12 March, p.82, 173), apart from ignoring that the scientific value is by no means the only value considered by conservationists, is based on several unacceptable assumptions.

In implying that conservation sites are primarily for the preservation of rare species Muir ignores the fact that most have been primarily designated in order to conserve particular vegetation types, associations of organisms, natural or semi-natural ecosystems. The argument that "value to science of any objects or phenomena lies not in themselves but in the information they yield to study. Once this information is recorded and published whatever value remains in the objects or phenomena is of no value to science" is ridiculous on two counts.

First, he specifies no criteria of "value" that are meaningful. He merely transfers the problem of what he means from conservation sites to published information about them. Even if one disregards this problem one is left, on his own arguments, with a strong case in favour of conservation sites. Ecology is still a young science and it has hardly scratched the surface in its study of the vast majority of ecosystem types. The rate of ecological advance does not compare favourably with the rate of loss of certain habitat types. There are, as yet, no vegetation types or ecosystems whose study has been exhausted to the extent that they are of no further interest to ecologists!

I am responsible for the "sites of special scientific interest" that make up the Malham Tarn Nature Reserve, one of the best documented nature reserves in the country. Its scientific documentation started with observations by John Ray in 1671 and has rapidly accelerated since 1947 . We now know enough to realize that it will require much more study than that already accomplished before any scientist would be other than foolish to suggest the site was of no further interst to science.

The tragedy of the present rate of loss of sites of special scientific interest is that we know so little of what is being lost. What little we do know strongly suggests that the Nature Conservancy Council have correctly identified the sites of greatest interest to science apart from them being those necessary if we are to achieve the conservationists' aim to convey the maximum diversity of wildlife into the next century. The conservationist is not, as Muir implies, trying to halt evolution. $\mathrm{He}$ is primarily concerned with the perpetuation of a diversity of habitat types. A variety of forest organisms depends on a variety of forest habitats - regardless of the rates of evolution of their organisms.

R.H.L. DiSney

Malham Tarn Field Centre, Settle, North Yorkshire, UK

\section{DMSO and immunity}

SiR - The observations of Pestronk and Drachman ${ }^{1}$ that dimethyl sulphoxide (DMSO) reduced anti-receptor antibody titres in experimental myasthenia gravis in rats are of considerable interest. The authors conclude: "It seems likely that DMSO might also be effective in ameliorating other active humoral immune responses. If so, DMSO may provide an effective new treatment for immune diseases mediated by autoantibodies.' Lest this statement lead once more to proclamations of DMSO as a wonder drug, several important points need an answer.

The $\mathrm{LD}_{50}$ of DMSO by intraperitoneal (i.p.) injection is between 10 and 11 per $\mathrm{kg}$ for rats and mice. Pestronk and Drachman injected $1.0 \mathrm{ml}$ of DMSO into rats daily for 14 days. Assuming a body weight of $250 \mathrm{~g}$ for a rat the dose of DMSO for each rat would be approximately $4 \mathrm{~g}$ per $\mathrm{kg}$, or 36 per cent of the acute $\mathrm{LD}_{50}$. The injection (i.p.) of this amount of DMSO into rats and mice produces a number of pharmacological and biological effects including an increase in peripheral blood pressure, changes in the oxygen levels, probable anoxia in the spleen and hypothermia 2,3 . In mice the level of hypothermia is severe, with rectal temperature reaching $33.5^{\circ} \mathrm{C}$ and recovery after a single injection of DMSO (4.5 g per $\mathrm{kg}$ ) takes more than $6 \mathrm{~h}$. Hypothermia represents a generalized but reversible toxicity. Many chemicals when injected at levels of approximately $20-40$ per cent of the $L_{50}$ produce similar effects.

Thus the clearly demonstrated effects of DMSO in decreasing antibody titres illustrated by Pestronk and Drachman may not be specific. In any event the possible therapeutic usefulness of a chemical effective at doses so close to the $\mathrm{LD}_{50}$ is unlikely to prove clinically acceptable.

\section{University of Victoria,}

M. J. AshwoOd-SMith

British Columbia, Canado

Pestronk, A. \& Drachman, D. B. Nature 288, 733-734 (1980)

. Ashwood-Smith, M. J. Thesis, Univ. London (1962).

3. Ashwood-Smith, M. J. Int. J. Radiat. Biol. 341,101 (1961) Ann N. Y. Acad. Sci. 141, 45-62 (1967).

SIR - The comments of Professor AshwoodSmith should serve as a useful reminder that the pharmacological actions of dimethyl sulphoxide must be carefully examined. The mechanism of action by which the drug suppresses anti-acetylcholine receptor antibodies in the experimental animal model of myasthenia gravis is not yet understood. Moreover, the reduction in serum antibody levels must be taken into account as a possible undesirable effect if the drug is contemplated for other clinical applications.

School of Medicine, DANIEL B. DRACHMAN

John Hopkins University.

Baltimore, Maryland, USA. 